\title{
最近の歯学
}

\section{4. 口腔病理}

$$
\begin{gathered}
\text { マイクロディセクション法を用いた Loss of Heterozygosity (LOH) による } \\
\text { 口腔多発癌のクロナリティの解析 }
\end{gathered}
$$

東京医科歯科大学歯学部口腔病理学講座 蔣 偉文, 坂本 啓, 高木 実

口腔扁平上皮癌は他の臓器の癌と比べると多発しやすいこ とが知られていて, 口腔癌の発生機序として field cancerizationの概念が提唱されている。しかし多発癌の定義は必ずし も明確でない。病理組織学的に多発した浸潤癌病巣の周囲に 異型上皮，上皮内癌などの前癌性病変を認めたときは，それ ぞれの腫瘍は原発性であると判断しているが，さらに正確な 判定法が望まれる。口腔扁平上皮癌の発生は上皮增殖，異型 上皮，上皮内癌，浸潤癌と連続して起こると考えられるが， すべての症例でこの変化を認めることはなく，むしろ突然に 正常上皮のなかに癌が発生することのほうが多い。口腔扁平 上皮癌の前癌性病変として白板症があり, われわれは白板症 の病変全体における異型性の違いの分布を検索しているが, この所見によれば癌化は白板症の病巣中で多発性に起こると 考之られる(図 1，2）。

最近 $\mathrm{LOH}$ の報告が多くなされるようになった。 染色体の非へテ口接合性の欠失を意味し，この方法を用いて 癌抑制遺伝子の検出ができるが, また一方では各染色体の標 識となるミクロサテライトマーカーを調べることも含めて, 離れた部位に多発して存在する癌細胞が同一の起源であるか ぞうかの判定方法として用いることもできる。口腔癌の LOHについては, 3 p, 4 q, 5 q, 7 q, 8 p, 9 q, 10 p, $11 \mathrm{q}, 17 \mathrm{q}, 18 \mathrm{q}$ などで起こることが知られている。へマトキ シリン・エオジン染色標本の観察により, 多発癌と考之られ る部位を同定し，パラフィン包埋標本を用いてマイクロディ

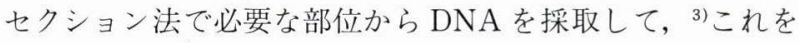
PCRにより解析することによってクロナリティを明らかに し，多発性かどうかを検定できる。われわれは現在これらの
研究を進めている。

\section{文献}

1) Wang, X. L., Uzawa, K., Imai, F. L. and Tanzawa, H. : Localization of a novel tumor suppressor gene associated with human oral cancer on chromosome 4 q 25. Oncogene 18:823-825, 1999.

2) Dolan, K., Garde, J., Gosney, J., Sissons, M., Wright, T., Kingsnorth, A. N., Walker, S. J., Sutton, R., Meltzer, S. J. and Field, J. K. : Allelotype analysis of oesophageal adenocarcinoma : loss of heterozygosity occurs at multiple sites. Br. J. Cancer 78 : 950-957, 1998.

3) Fujii, H., Marsh, C., Cairns, P., Sidransky, D. and Gabrielson, E. : Genetic divergence in the clonal evolution of breast cancer. Cancer Res. $56: 1493-1497$, 1996.

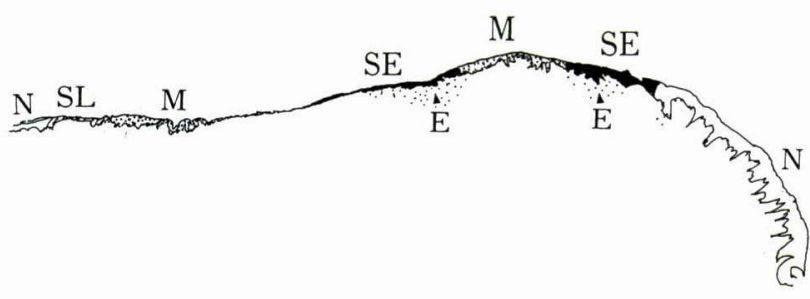

図2四1の模式図で, 癌化が2力所（矢頭）で起こってい る。

$\mathrm{E}$ : early carcinoma, $\mathrm{SE}$ : severe dysplasia, $\mathrm{M}$ : moderate dysplasia, SL : slight dysplasia, N : normal mucosa

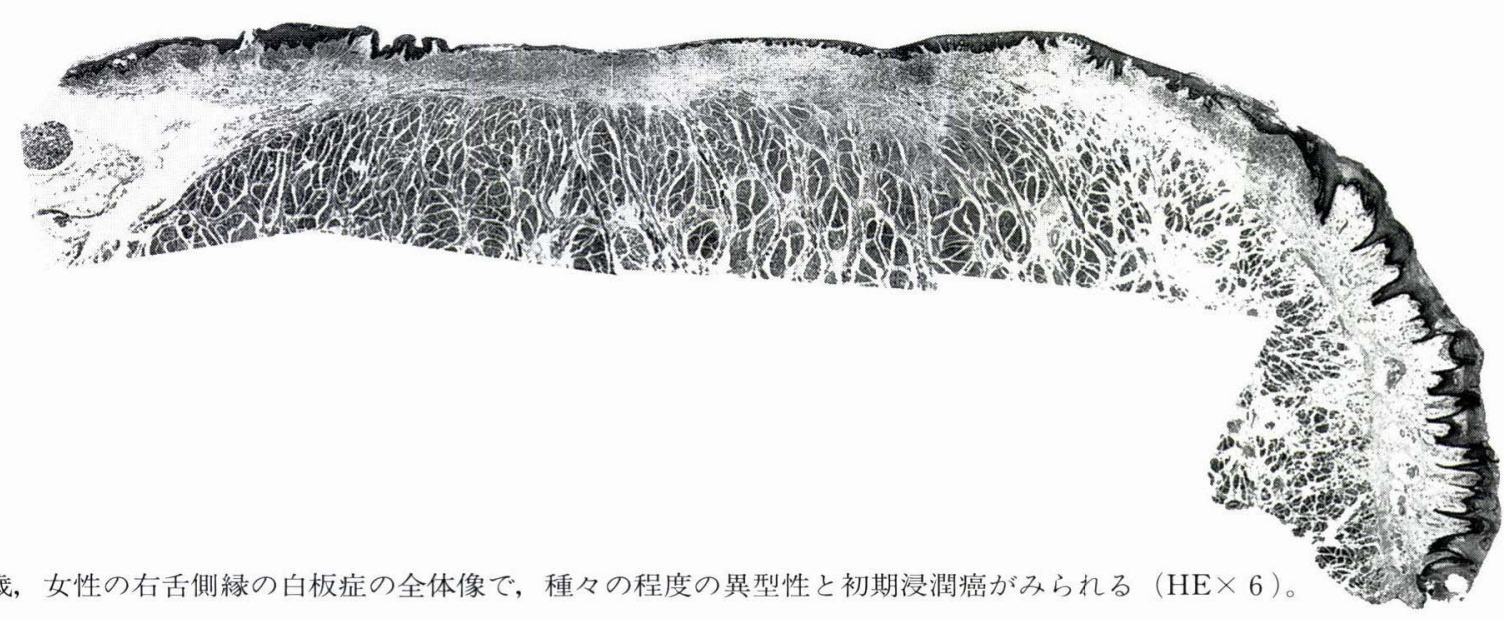

図 161 歳, 女性の右舌側縁の白板症の全体像で, 種々の程度の異型性と初期浸潤癌がみられる（HE $\times 6)$ 